Instructions for authors, subscriptions and further details:

http://ijep.hipatiapress.com

\title{
A New Context Affording for Regulation: The Case of Musical Play
}

Antonia Zachariou, ${ }^{1,2}$ David Whitebread ${ }^{2}$

1) University of Roehampton

2) University of Cambridge

Date of publication: October $24^{\text {th }}, 2017$

Edition period: October 2017 - February 2018

To cite this article: Zachariou, A. \& Whitebread, D. (2017). A New Context Affording for Regulation: The Case of Musical Play. International Journal of Educational Psychology, 6(3), 212-249. doi: 10.17583/ijep.2017.2959

To link this article: http://dx.doi.org/10.17583/ijep.2017.2959

\section{PLEASE SCROLL DOWN FOR ARTICLE}

The terms and conditions of use are related to the Open Journal System and to Creative Commons Attribution License (CC-BY). 


\section{A New Context Affording for Regulation: The Case of Musical Play}
Antonia Zachariou
David Whitebread
University of Roehampton
University of Cambridge

\section{Abstract}

The present study set out to investigate theoretical speculations that regulation and musical play, an initial manifestation of musicality, are directly linked. This study aimed to explore the potential for regulation to occur during musical play and investigate the nature of the regulatory behaviours. Thirty-six children, aged 6 and 8 , were observed during musical play sessions. These observations were analysed, using a coding framework, to identify and code regulatory behaviours as to the type of regulation, its social nature and the direction of activity. The data were subjected to quantitative analysis. The findings suggest that regulatory behaviours occurred during musical play. During musical play tasks, cognitive monitoring and emotional/motivational monitoring behaviours were the most prevalent, significantly more opportunities were provided for socially-shared regulation compared to self- or co-regulation, and the children more often directed their activity towards fundamental, rather than superficial aspects of tasks. The results can inform theory and practice.

Keywords: Self-regulation, co-regulation, socially-shared regulation, musical play, musicality 


\title{
Un Nuevo Contexto
}

\section{Favorecedor de la Regulación: El Caso del Juego Musical}

\author{
Antonia Zachariou \\ University of Roehampton
}

David Whitebread

University of Cambridge

\section{Resumen}

El presente estudio se propuso investigar las especulaciones teóricas de que la regulación y el juego musical, una manifestación inicial de la musicalidad, están directamente vinculados. Este estudio tuvo como objetivo explorar el potencial de regulación que se produce durante el juego musical e investigar la naturaleza de los comportamientos regulatorios. Treinta y seis niños, de entre 6 y 8 años, fueron observados durante las sesiones de juego musical. Estas observaciones fueron analizadas, utilizando un marco de codificación, para identificar y codificar comportamientos regulatorios en cuanto al tipo de regulación, su naturaleza social y la dirección de la actividad. Los datos fueron sometidos a un análisis cuantitativo. Los hallazgos sugieren que se produjeron comportamientos regulatorios durante el juego musical. Durante las tareas de juego musical, el monitoreo cognitivo y los comportamientos de monitoreo emocional / motivacional fueron los más prevalentes, se brindaron significativamente más oportunidades para la regulación compartida socialmente en comparación con la auto- o la corregulación, y los niños dirigieron su actividad más frecuentemente hacia lo fundamental, en lugar de aspectos superficiales de las tareas. Los resultados pueden informar teoría y práctica.

Palabras clave: Autorregulación, corregulación, regulación social compartida, juego musical, musicalidad. 
$\neg$ he present study comprises an innovative endeavour to bring together research from two separate research strands: self-regulation ${ }^{1}$ and musicality; both argued to be fundamental in children's lives (e.g. Bronson, 2000; Trevarthen, 2000). The two are examined separately, and are then brought together to articulate the research aim.

\section{Self-regulation}

Self-regulation is considered crucially important for children's development as learners (Baumeister \& Vohs, 2004; Bronson, 2000; Hacker, Dunlosky, \& Graesser, 1998; McClelland \& Tominey, 2011). The model adopted for the purposes of this study considers self-regulation as the monitoring and control of all aspects of human behaviour, including cognitive, emotional, social and motivational elements (e.g. Boekaerts \& Niemivirta, 2000; Bronson, 2000), while acknowledging metacognition as the central cognitive element of selfregulation (Whitebread et al., 2010). The present study relies heavily on the model developed by Whitebread and colleagues (2009b), which draws together the literature on self-regulation and suggests three basic elements of self-regulation: metacognitive knowledge (the individual's knowledge about personal, task and strategy variables affecting their cognitive performance), metacognitive regulation (i.e. the metacognitive processes during ongoing activities involving planning, monitoring, control and evaluation) and finally the monitoring and control of emotions and motivational states during learning tasks.

\section{Early Emergence and Development}

Self-regulation appears very early on in children's lives. Vygotsky (1978) argued that children move from being 'other-regulated' to being 'selfregulated'. The emergence of early self- and social-regulation processes has been evidenced in very young pre-verbal children, when pre-verbal means (such as gestures) of communicating meaning between infants and their caregivers are studied (Rodríguez \& Palacios, 2007; Vallotton, 2008). Most recently, Brinck and Liljenfors (2013) brought together evidence to argue that metacognition has its developmental origin in early 'proto-conversations' (Bateson, 1979, as cited in Trevarthen, 2012) between infants and adults. 
Within these proto-conversations and in an effort to maintain intersubjectivity (a shared understanding), monitoring and control strategies acquire inherent, pragmatic importance to the child. Hence, proto-conversations become a pragmatic context where infants internalise and construct monitoring and control strategies.

Self-regulatory skills have been argued to develop through children's engagement in playful activities (Bruner, 1972). When children play with peers, they act in their Zone of Proximal Development (ZPD), while trying to maintain intersubjectivity and by mutually scaffolding each other (Vygotsky, 1978). Make-believe play has attracted the majority of research in this area. This research suggests that make-believe's play specific characteristics, such as its rule-based nature, affordance for self-regulating language, (Berk, Mann, \& Ogan, 2006; Vygotsky, 1978) and emotional regulation (Fantuzzo, Sekino, \& Cohen, 2004; Galyer \& Evans, 2001), encourage self-regulatory development.

One of the most cited studies in this area, which provides evidence that even young children can self-regulate in playful, and hence meaningful, contexts was the CIndLe study (Whitebread et al., 2009a, b). In this study, 3to 5-year-old children from 32 classes were video-recorded over a period of two years, during class and play time. Self-regulatory events mostly occurred during playful activities, where on average 6.92 regulatory behaviours per minute were recorded. This study reported that different areas of selfregulatory behaviours appeared at different rates, with metacognitive regulation being the most prevalent, followed by metacognitive knowledge, and emotional/motivational regulation behaviours being the least frequent (Whitebread et al. 2009a). More specifically, playful situations appeared to mainly promote monitoring, control and planning behaviours (Whitebread et al, 2009b)

\section{The Social Nature of Self-regulation}

Notwithstanding the traditional focus on the individual element of selfregulated learning (Zimmerman, 1989), the social nature of regulation is currently an increasingly central theme (Hadwin, Oshige, Gress, \& Winne, 2010; Volet, Vauras, \& Salonen, 2009). Current research suggests that, apart from self-regulated learning, attention should be directed towards co- 


\section{Zachariou \& Whitebread-New Context Affording for Regulation}

regulation and socially-shared regulation (Hadwin, Järvelä, \& Miller, 2011; Iiskala, Vauras, \& Lehtinen, 2004).

In fact, the traditional definition of self-regulation employed above could be considered a more general definition of regulation, with the terms self-, coand socially-shared regulation only employed when a differentiation between the regulation's social intentionality is to be made. To this end, self-regulated learning refers to regulating one's own learning and can be evident in both solo and collaborative tasks, while co-regulation is jointly negotiated and occurs in unequal situations when one partner masters a key element of the task but the other does not. Socially-shared regulation describes the egalitarian, complementary regulation of a task, with its ultimate goal being to co-construct regulation (Grau \& Whitebread, 2012; Hadwin et al., 2010, 2011; Iiskala, et al., 2004; Järvelä \& Hadwin, 2013).

Socially-shared regulation is often associated with higher performance and learning outcomes during collaborative tasks (Grau \& Whitebread, 2012; Janssen, Erkens, Kirschner, \& Kanselaar, 2012; Järvelä, Järvenoja, Malmberg, \& Hadwin, 2013). Nonetheless, research findings present selfregulation as the most frequently coded type of social intentionality in children's group-work (Whitebread et al., 2007), and highlight a relative absence of high-level socially-shared regulation (Hurme \& Järvelä, 2005). Evidently, the group nature of tasks is not sufficient prerequisite for sociallyshared regulation to evolve. To this end, Perry and Winne (2013) and Winne, Hadwin and Perry (2013) stress the importance of tasks which prompt interdependent, dynamic, and coordinated work.

\section{The Quality of Regulatory Behaviour}

The interest in studying the quality of regulatory behaviour was pioneered by the aspiration to identify instances of productive and high level regulation. For example, Grau and Whitebread's (2012) research, on social aspects of children's self-regulated learning in primary science classes, identified the need to code for regulatory behaviours directed towards qualitatively different aspects of children's work. Their codes described whether each behaviour was directed to regulate the development of the task (fundamental or surface level), aspects related to the organisation of the group-work or socioemotional aspects of the group-work. 
The appearance of more positive qualitative aspects of regulation has been reported to facilitate higher quality regulation (Grau \& Whitebread, 2012; Rogat \& Linnenbrink-Garcia, 2011) . Nonetheless, recent research suggests that children, rather than regulating content understanding or fundamental aspects of tasks, often spend a considerable amount of time on superficial task components which are associated with lower quality regulation (Grau \& Whitebread, 2012; Rogat \& Linnenbrick-Garcia, 2011).

Therefore, it appears that simply examining the type of regulation exhibited cannot account for the overall effectiveness and quality of regulation. It is important to go beyond identifying the frequency of observed regulatory behaviours and move towards also investigating the quality differences in children's regulatory behaviour (Hurme, \& Jarvela, 2005; Rogat, \& Linnenbrick-Garcia, 2011). To address this, a separate hypothesis investigating the directions of activity was tested in this study.

\section{Musicality}

Defining musicality proves to be a very challenging endeavour (Hallam, 2007). The notion of musicality employed in this paper has been used in studies of communication between infants and adults, advocating for their innate musical character (e.g. Papousek, 1996; Trevarthen, 2000). This could more accurately be defined as communicative musicality: the 'human impulse to create and share music'(Trevarthen, 2012, p.259).

Musicality, in the notion of communicative musicality, has attracted a wealth of research supporting the view that music is fundamental in human lives and development. The first interactions between infants and caregivers, termed 'proto-conversations' (Bateson 1979, as cited in Trevarthen, 2012), are inherently musical, and underpinned by biological predispositions (Papousek, 1996; Trevarthen, 2000). In these proto-conversations, intersubjectivity is an essential attribute for successful communication (Trevarthen, \& Aitken, 2001) and thus for the successful development of musicality. It should be noted here that the intersubjectivity required in these proto-conversations is also considered to be the basis on which metacognitive development is constructed (see Brinck \& Liljenfors, 2013). Hence, a direct 
link between musicality and self-regulation could be argued in that they both have their origins in proto-conversations.

\section{Musical Play}

The young child employs the 'internalised templates', built through the communicative and reciprocal interactions with the caregiver, as a source of musical play behaviours (Young, 2005). Musical play is universal and entails vocalisations, rhythmic bodily movement and play with sound-making objects (Tarnowski, 1999; Young, 2005) while allowing for exploration, improvisation and creation with sound (Lew \& Campbell, 2005; Littleton, as cited in Tarnowski, 1999). In the present study, 'musical play' refers to the prevalent -in the literature- types of musical play: hand-clapping games, circle games, movement play, singing play and instrumental play (Harwood, 1998; Lew \& Campbell, 2005; Marsh \&Young, 2007; Pond, 1980; Tarnowski, 1999; Young, 2003, 2004).

Musical play shares many of the characteristics of other playful contexts, such as make-believe, that effectively foster self-regulation (Zachariou \& Whitebread, 2015). These would include its rule-based nature (Marsh, 2008; Marsh \& Young, 2007) and its reinforcement of self-regulatory language and emotional self-regulation (Bannan \& Woodward, 2009; Barrett, 2009). Furthermore, musical play could potentially be a fertile ground for selfregulation, since it affords for early expertise (Custodero, 2009), social interaction, co-operation and co-regulation (Pound, 2010; Young, 2004), and by its very nature, encourages creativity, problem solving and exploration (Pound, 2010; Tarnowski, 1999). Bearing in mind that the fundamental characteristics that encourage the creation of the ZPD, such as intersubjectivity and scaffolding, are also evident in musical play (Bannan \& Woodward, 2009; Marsh, 2008; Marsh \& Young, 2007; Young, 2005) it appears that musical play could be a powerful context to support the development of children's self-and socially-shared regulatory abilities.

\section{Self-regulation and Musical Play}

This paper argues that musical play is a particularly powerful context affording opportunities for self-regulation. Theoretically, a direct link 
between musical play and self-regulation could be argued in that they both have their basis in the intersubjectivity originating in the proto-conversations. The fundamental characteristics that encourage the creation of the ZPD, such as intersubjectivity and scaffolding, are evident in musical play (Bannan \& Woodward, 2009; Marsh, 2008; Marsh \& Young, 2007; Young, 2005). This is supported by recent research reporting that musical play, when conducted in groups, 'has the potential to intensify the intersubjective experience' between the players, based on the atmosphere it induces and the underlying cognitive mechanisms that are required for successful musical play (Rabinowitch, Cross, \& Burnard, 2012, p.118). Scaffolding is also evident in musical play. In musical play, 'social synchrony' is an underlying value (Harwood \& Marsh, 2012, p.326). It is, thus, usual that more adept children engage in playful tuition of novice players by scaffolding their peers' learning through adjusting the games or modelling to a level slightly beyond their peers' current abilities (Marsh \& Young, 2007).

Research studying musical play in relation to self-regulatory behaviours is scarce. Self-regulatory behaviours during musical play have been incidentally reported by ethnographic studies (Harwood, 1998), without being named as such. The only two pieces of research so far explicitly targeting the relationships between self-regulation and musical play had their shortcomings. In the first, Winsler, Ducenne, and Koury (2011) compared 3and 4-year-old children who had participated in music and movement classes (incorporating musical play) with controls, on their performance on laboratory self-regulation tasks. The findings suggested that children who were enrolled in music classes showed better self-regulation and used more self-regulatory language in the form of private speech. Nonetheless, the artificial setting, in which this study assessed children's self-regulation, limited the insights that could be gained from studying children's self-regulation during musical play. In the second study, Zachariou and Whitebread (2015) attempted to explore children's regulatory behaviours during musical play activities. An observational approach was adopted and the study was carried out in an elementary classroom in Cyprus by observing ten children aged 6 to 7 years engaged in musical play during their music lessons. Nonetheless, the results of this study remain tentative because of its small and particular sample and further research on a wider sample is clearly needed. 
It was therefore considered worthwhile to undertake a larger study to explore further whether active engagement in musical play affords for the emergence of self-regulatory behaviours.

\section{Aim, Research Question and Hypotheses}

The present study's principal aim was to investigate the potential for regulation to occur during musical play. The present paper focuses on exploring whether or not regulatory ${ }^{2}$ behaviours appear during musical play and investigating the nature of this regulation. Based on findings within the literature concerning regulation in children in various contexts, as reviewed above, specific hypotheses were tested, as follows:

Hypothesis 1: Different types of regulatory behaviours appear at different rates during children's musical play.

Hypothesis 2: Regulatory behaviours of different social intentionality (self-, co-, and socially-shared regulation) appear at different rates during children's musical play.

Hypothesis 3: Different directions of activity (towards fundamental, surface or group organisation aspects) appear at differing degrees during children's metacognitive regulation behaviours within musical play.

\section{Methods}

\section{Sample}

Participants were 36 Cypriot children coming from 6 different classes. A multilevel mixed-methods sampling technique (Teddlie \& Yu, 2007) was employed. At the first level, purposive sampling took place in order to choose five (one taught two classes) music teachers. The crucial criterion when choosing the music teachers leading the musical play sessions was that they were very competent and confident (Pound, 2010), as well as willing to incorporate musical play into their music lessons. The five participating teachers were identified in consultation with music inspectors and one of the leading academic experts in music education in Cyprus. All the participating music teachers were highly experienced and qualified (three of them were 
either holders of or working towards $\mathrm{PhDs}$ and/or master's degrees in music education).

At the second level, purposive sampling of children took place within the classes of these teachers using criterion sampling to choose six children from each class. The sampling aimed to have a representative sample of children across the range of regulatory abilities, as identified through the CHILD checklist $^{3}$ (Whitebread et al., 2009b). In Year 1, 18 children participated in the study and had a mean age of 78 months ( 6 years and 6 months) at the beginning of the study (range:70-81 months). In Year 3, the 18 children had a mean age of 101 months (8 years and 5 months, range: 97-107 months). In both year-groups, half of the children were girls.

\section{Procedure and Measures}

This study was strongly based on observational methods and developed within a socio-cultural framework. The study was implemented in Cyprus, at five different rural and urban primary schools. The children were observed during musical play sessions taking place in their music classes, where a repertoire of musical play activities was implemented. These observations were analysed, using a coding framework developed for the purposes of this study, to identify and code any regulatory behaviours.

\section{Research design}

Initially, the music teachers were informed of the aims, main concepts and procedures of the study. The rationale for informing the teachers was that in order to fully engage teachers' commitment, secure a rich execution of the innovation and increase the possibility that teachers will incorporate the innovation in their ongoing practice, it was essential that they were fully informed about the underlying theoretical foundations and purposes of the innovation (Coltman, Warwick, Wilmott, Pino-Pasternak, \& Whitebread, 2013). This was also an important step in establishing rapport with the teachers and aided in maintaining open communication channels with the music teachers throughout the study.

Preliminary observations of the music classes took place, so that the children would become familiar with the presence of the observer, camcorders and microphones in their classes. Following this, five musical play sessions 


\section{Zachariou \& Whitebread-New Context Affording for Regulation}

were implemented in each class over five consecutive weeks. Each musical play session was dedicated to a different type of musical play (movement, instrumental, singing play, hand-clapping or circle games), and lasted approximately 30 minutes. Detailed lesson plans were created for all the sessions (see Appendix A for examples of activities). The sessions were video-recorded and an 'observer as participant' approach was adopted. The video-recordings were subsequently coded on the basis of a coding framework.

The play tasks introduced to the children contained elements of free play, yet mainly afforded 'guided play'. Thus the children's play was most often sensitively and responsively guided by an adult, within a meaningful for the children context. Extensive research advocates for guided play being a powerful tool for teaching and learning, with catalytic effects on children's intellectual, emotional, social, and linguistic development (Golinkoff, HirshPasek, \& Singer, 2008; Hirsh-Pasek, Golinkoff, Berk and Singer, 2008).

In order to be coherent with the research purpose to explore the potential for regulatory behaviours to occur during musical play, the development of the musical play activities was based on literature related to contexts promoting regulatory development, since in this way it was more likely for this potential to be unveiled. Activities were devised in order to be interesting, challenging and open-ended, affording opportunities for children to control the level of challenge (McCaslin \& Good, 1996; Veenman, 2011; Veenman et al., 2006; Whitebread, 2013). They also provided ample opportunities for collaborative group work and various kinds of peer-tutoring, since there is growing evidence that such collaborative forms of learning are able to enhance regulatory behaviour in classroom situations (Iiskala et al., 2004; Whitebread et al., 2007), but also facilitate the identification of regulatory behaviour by obliging the participants to externalize and articulate their ideas and conceptions to others (Iiskala et al., 2004). Additionally, when designing tasks to evoke socially-shared regulation, as discussed above, a key ingredient is the need for interdependence within the tasks (See The social nature of selfregulation section) and, given that musical play's inherent characteristics promote interdependence in the group (See Self-regulation and musical play section), every effort was made to accentuate and fully exploit this characteristic of musical play. 


\section{Coding framework}

Children's regulatory behaviour during the musical play activities was assessed employing an observational framework for coding all regulatory behaviours identified during musical play.

The basis of the study's coding framework was the C.Ind.Le coding framework (Whitebread et al., 2009b); an internationally used and validated framework enabling the identification of behaviours indicative of metacognitive knowledge (of persons, tasks and strategies), of metacognitive regulation (planning, monitoring, control and evaluation) and emotional and motivational regulation (monitoring and control). Therefore, every identified regulatory behaviour was coded as to the type of regulation it involved (according to the C.Ind.Le framework, see Whitebread et al., 2009b). Indicative examples of how each type of regulatory behaviour manifested during musical play are presented in Appendix B.

Furthermore, respecting the distinctive character of musical play and in order to investigate the second hypothesis of this study, every identified regulatory behaviour was also coded as to its social intentionality. Each regulatory behaviour was coded as to whether it involved self-, co- or sociallyshared regulation (adapted by Grau \& Whitebread, 2012; Hadwin et al., 2010, 2011; Iiskala et al., 2004). Examples of how each type of social intentionality manifested in regulation during musical play are provided in Appendix C.

Finally, metacognitive regulation behaviours were also coded according to the direction of the activity. Each regulatory behaviour was coded as to whether it was directed towards fundamental, surface or group-work organisational aspects of the task (adapted from Grau and Whitebread, 2012). Regulatory behaviour directed towards fundamental aspects included behaviour that was necessary for the completion of the task. The code 'surface aspects' was assigned to behaviours regarding more contingent aspects of the task, which were mostly not essential in terms of the final quality of the work produced by the group. The code 'organisation of group-work' was assigned to metacognitive regulation behaviours that concerned coordinating the team work. Appendix D provides examples of regulatory behaviours under each of the three different directions of activity. 


\section{Zachariou \& Whitebread-New Context Affording for Regulation}

\section{Data Analysis Strategy}

First the data was prepared for the analysis on the Observer XT10 software. Only clear musical play events (children being actively and evidently engaged in musical play) underwent observational coding. A detailed protocol analysis procedure was followed; each regulatory behaviour was coded as a point event, assigned one of the nine main codes for type of regulatory behaviour, then defined as to its social intentionality and direction of activity. More than $10 \%$ of the data were coded by a second observer. Percentages of agreement for unitising the data (i.e. agreeing on which units of behaviour should be coded) were above $69 \%$, a result which compares favourably with similar studies (Whitebread et al., 2009). Cohen's Kappa was calculated to establish whether the dually coded behaviours were assigned the same codes, and this demonstrated a high level of agreement with $\mathrm{k}=.89$.

A data profile for each hypothesis was developed on the Observer XT and behaviour analysis took place, which allowed for extracting the counts and rates for the behaviours under investigation for statistical analysis. All the parametric assumptions were checked and indicated that the assumption of normality was tenable for most variables, with a few exceptions indicating possible, mostly marginal violations of normality. Due to this, and given the relatively small sample size of the study, it was decided that for each statistical test both the parametric and non-parametric alternatives were run. When their results were dissimilar or more than one indication of violations of assumptions was evident, a square root transformation was applied. Mixeddesign ANOVAs $(2 \times 3$ or $2 \times 9)$ were run, since all the questions involved two independent variables. One independent variable was a repeated-measures variable ( $\mathrm{H} 1$ : type of regulatory behaviour, $\mathrm{H} 2$ : type of social intentionality, H3: type of direction of activity) and the other one a between-group variable (age-groups). Within the larger study, all analyses explored the differences between both different regulatory behaviours and age-groups. However, for the purposes of this paper, only the former are presented. A Bonferroni correction was applied to all the post-hoc tests and all effects were reported to a level of significance correcting for the number of comparisons conducted. 


\section{Results}

Hypothesis 1: Different Types of Regulatory Behaviours Appear at Different Rates During Children's Musical Play

During the clear musical play episodes $(M=55.14$ minutes per child, $S D=10.28$ ), a mean of 437.19 regulatory behaviours per child was coded $(S D=166.66)$. This accounts for a mean rate of 7.83 regulatory behaviours per minute per child $(S D=2.32)$.

The frequencies and relative percentages of the production of behaviours indicating the different areas of regulation in the C.Ind.Le Coding Framework during the five sessions of musical play are reported in Table 1. All the general areas of regulation in the C.Ind.Le coding framework (metacognitive knowledge, metacognitive regulation, emotional/ motivational regulation) were manifested during the five sessions of musical play. The same was the case for all the specific regulatory behaviours within these broader areas (knowledge of persons, tasks and strategies, planning, monitoring, control, evaluation, emotional/motivational monitoring and control). 
Table 1

Distribution of children's regulatory behaviours during musical play to areas of regulatory behaviour and specific regulatory behaviours

\begin{tabular}{|c|c|c|c|c|}
\hline $\begin{array}{l}\text { Regulatory area } \\
\text { Regulatory behaviour }\end{array}$ & $\begin{array}{l}\text { Mean } \\
\text { number of } \\
\text { regulatory } \\
\text { behaviours }\end{array}$ & $\begin{array}{l}\text { Percentage of } \\
\text { the total } \\
\text { regulatory } \\
\text { behaviours }\end{array}$ & $\begin{array}{l}\text { Mean rate of } \\
\text { regulatory } \\
\text { behaviours } \\
\text { per minute }\end{array}$ & $\begin{array}{l}\text { SD of rates } \\
\text { of } \\
\text { regulatory } \\
\text { behaviours }\end{array}$ \\
\hline $\begin{array}{l}\text { Metacognitive } \\
\text { knowledge }\end{array}$ & 10.36 & $2.37 \%$ & 0.18 & 0.11 \\
\hline Knowledge of persons & 4.39 & $1.00 \%$ & 0.08 & 0.05 \\
\hline Knowledge of tasks & 2.28 & $.52 \%$ & 0.04 & 0.04 \\
\hline $\begin{array}{l}\text { Knowledge } \\
\text { strategies }\end{array}$ & 3.69 & $.84 \%$ & 0.06 & 0.05 \\
\hline $\begin{array}{l}\text { Metacognitive } \\
\text { regulation }\end{array}$ & 290.72 & $66.50 \%$ & 5.19 & 1.72 \\
\hline Planning & 63.33 & $14.49 \%$ & 1.12 & .39 \\
\hline Monitoring & 156.75 & $35.85 \%$ & 2.81 & 0.92 \\
\hline Control & 59.94 & $13.71 \%$ & 1.07 & 0.48 \\
\hline Evaluation & 10.69 & $2.45 \%$ & 0.19 & 0.11 \\
\hline $\begin{array}{l}\text { Emotional and } \\
\text { motivational regulation }\end{array}$ & 136.11 & $31.13 \%$ & 2.46 & 0.62 \\
\hline $\begin{array}{l}\text { Emotional/motivational } \\
\text { monitoring }\end{array}$ & 121.81 & $27.86 \%$ & 2.20 & 0.55 \\
\hline $\begin{array}{l}\text { Emotional/motivational } \\
\text { control }\end{array}$ & 14.31 & $3.27 \%$ & 0.26 & 0.14 \\
\hline $\begin{array}{ll}\text { Overall regulatory } \\
\text { behaviours }\end{array}$ & 437.19 & $100 \%$ & 7.83 & 2.32 \\
\hline
\end{tabular}

Distribution on the basis of the C.Ind.Le coding framework

It is also evident that different general and specific regulatory behaviours appeared at different rates during musical play. A mixed-design ANOVA indicated that there was a significant main effect of the general area of regulation on the rates of regulation shown by the child, $F(1.14,38.70)=$ 
$337.35, p<.001$. This result indicates that, when all other variables are ignored, the rates differed according to the area of regulatory behaviour shown by the child. Because Mauchly's test indicated that the assumption of sphericity had been violated $\chi^{2}(2)=46.68, p<.001$, multivariate tests are also reported ( $\varepsilon=$ $.57)$. These showed a statistically significant difference between the areas of regulatory behaviour during the episodes of musical play, $V=0.96, F(2,33)$ $=378.56, p<.001$. Post-hoc tests corroborated the differences graphically presented in Figure 1. The rate of metacognitive regulation behaviours $(M=$ 5.19) was significantly higher than the rate of emotional/motivational regulation behaviours $(M=2.46), p<.001, r=.91$, which in turn was significantly higher than metacognitive knowledge behaviours $(M=0.18), p$ $<.001, r=.98$.

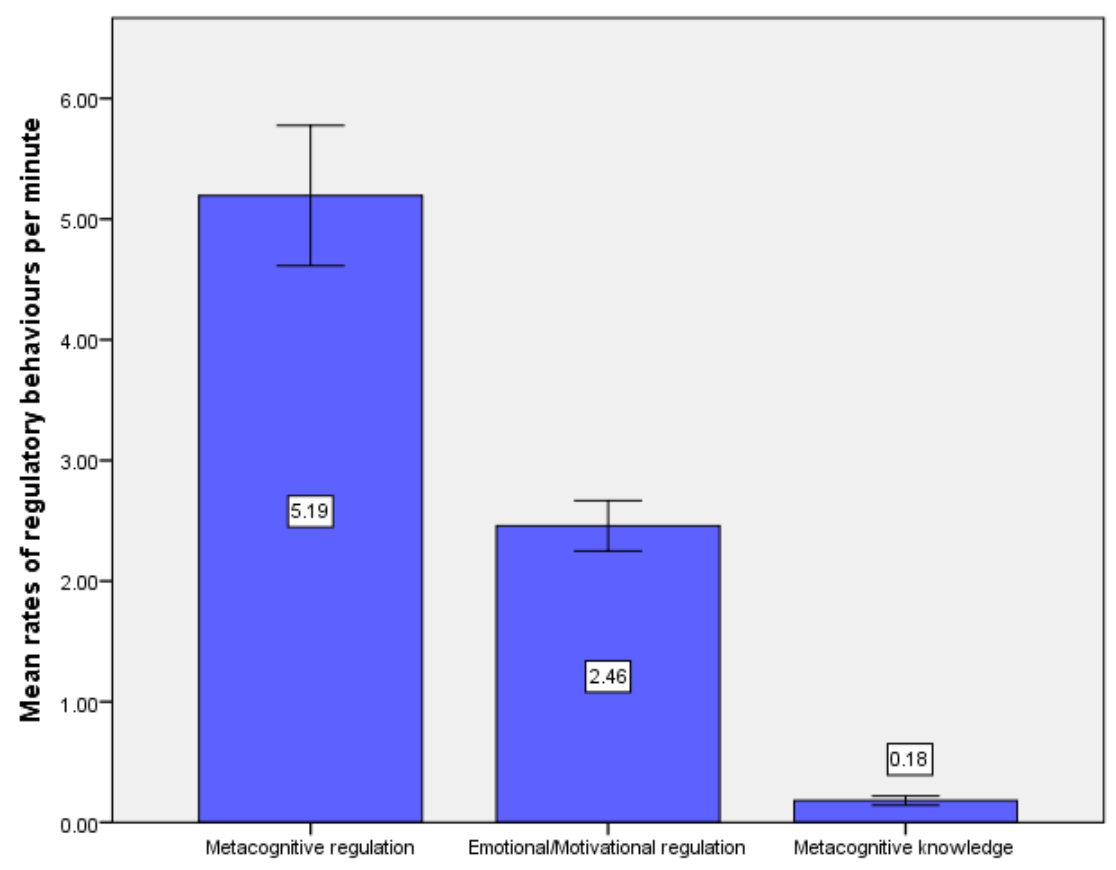

Error Bars represent the $95 \%$ confidence interval

Figure 1. Bar graph of mean rates per area of regulatory behaviour during musical play. 
Before running a mixed-design ANOVA on the specific types of regulation, a square root transformation was applied to all the variables since both the normality tests agreed that some of the variables had violated the assumption of normality. There was a significant main effect of the specific type of regulatory behaviour on the frequency of regulation shown by the child, $F(5.18,175.96)=809.84, p<.001$. Since Mauchly's test indicated that the assumption of sphericity had been violated $\chi^{2}(35)=65.30, p=.002$, multivariate tests are reported $(\varepsilon=.65)$ which agreed with the above result, $V$ $=0.99, F(8,27)=730.66, p<.001$.

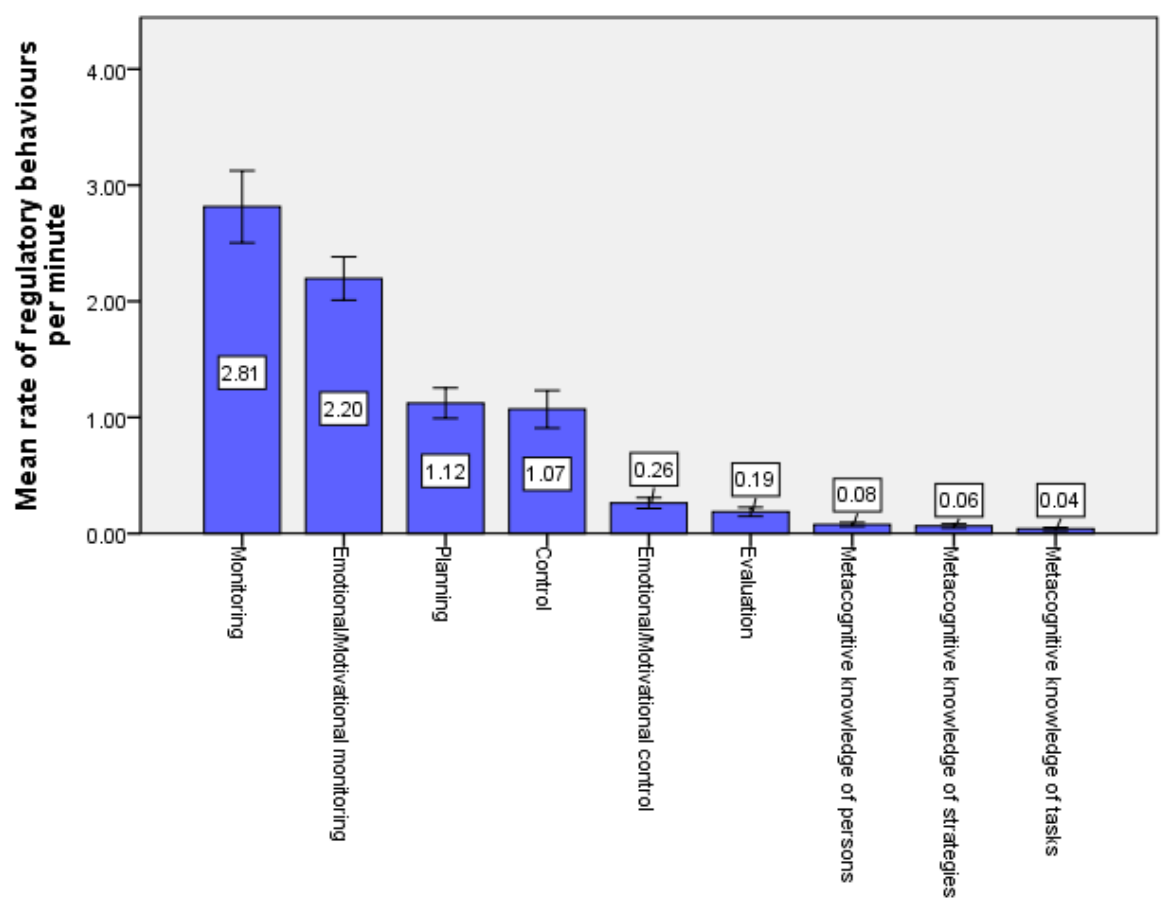

Error Bars represent the $95 \%$ confidence interval

Figure 2. Bar graph of mean rates per specific regulatory behaviour during musical play 
The post-hoc tests showed that almost all of the regulatory behaviours were significantly different to the remainder. Starting from the most frequently appearing (see Figure 2), the rate of monitoring behaviours $(M=2.81)$ was significantly higher than the rate of emotional/motivational monitoring behaviours $(M=2.20, p<.001)$, which in turn was significantly higher than planning $(M=1.12)$ and control $(M=1.07, p<.001)$. Planning and control were not significantly different from each other $(p=1)$ and could therefore be considered as sharing the third position in frequency. They were, however, significantly higher than emotional/motivational control $(M=0.26, p<.001)$, which in turn was significantly higher than evaluation $(M=0.19, p=.04)$. Evaluation was significantly higher than metacognitive knowledge of persons $(M=0.08)$ and strategies $(M=0.06, p<.001$ for both). Metacognitive knowledge of persons was significantly higher than the metacognitive knowledge of tasks $(M=0.04, p=.04)$. Metacognitive knowledge of strategies was not significantly different from either metacognitive knowledge of persons $(p=1)$ or metacognitive knowledge of tasks $(p=.40)$.

Therefore, monitoring behaviours were the prevalent regulatory behaviours during musical play, followed closely by emotional/motivational monitoring behaviours. Planning and control behaviours also appeared more frequently than the remainder of the regulatory behaviours.

\section{Hypothesis 2: Regulatory Behaviours of Different Social intentionality (self-, co-, and socially-shared regulation) Appear at Different Rates during Children's Musical Play}

During musical play the children demonstrated regulatory behaviours on all three different levels of social intentionality that is self-regulation, coregulation and socially-shared regulation, all of which were observed at different rates.

There was a significant main effect of the social intentionality of regulation (self-regulation, co-regulation and socially-shared regulation) on the rate of regulatory behaviours shown by children, $F(1.82,61.91)=80.29, p<.001$. Mauchly's test indicated that the assumption of sphericity had been violated $\chi^{2}(2)=6.69, p=.04$, so multivariate tests are reported $(\varepsilon=.85)$. This result indicates that the rates were different according to the social intentionality of 
the regulatory behaviour shown by the child; a result corroborated by the multivariate tests' results, $V=.81, F(2,33)=68.74, p<.001$.

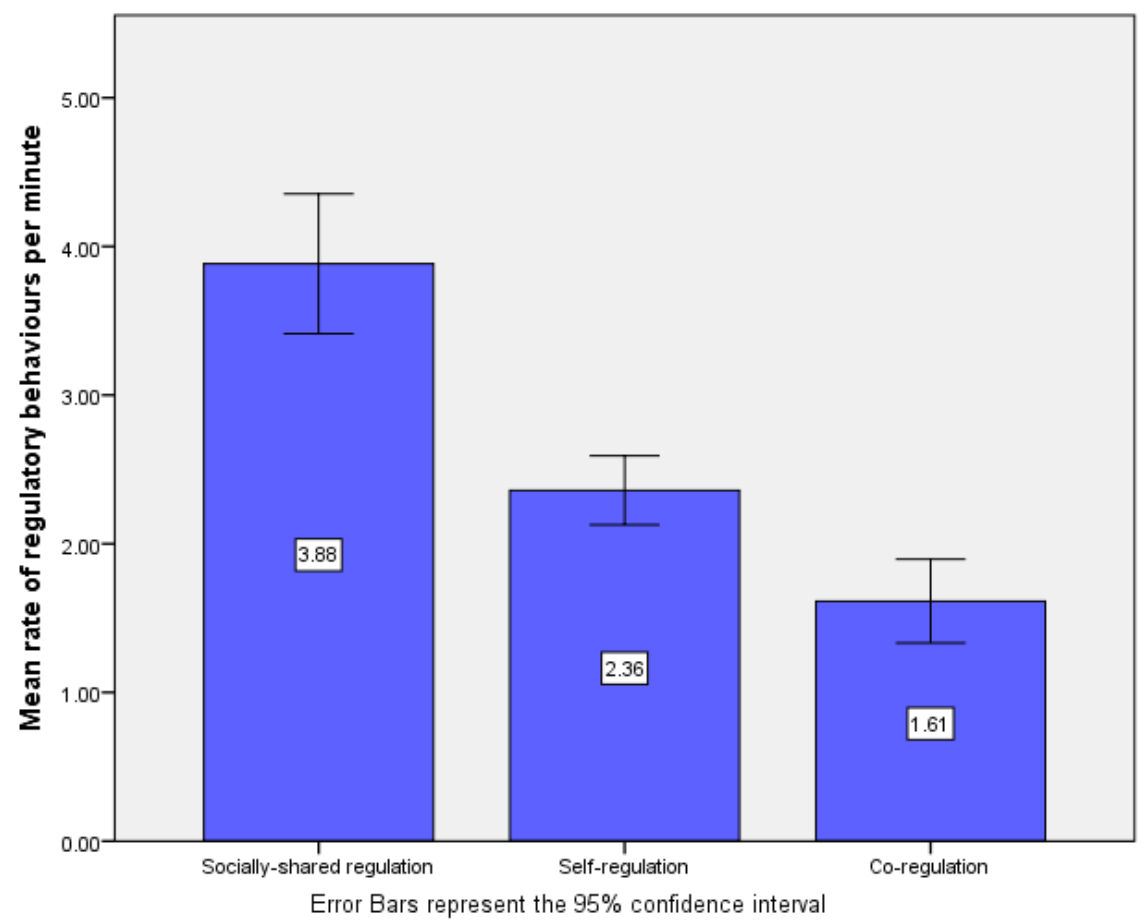

Figure 3. Bar graph of mean rates per different social intentionality during musical play.

According to post-hoc tests all the regulatory behaviours of different social intentionality appeared at significantly different rates from each other (Figure 3). Socially-shared regulation behaviours $(M=3.88, S D=1.39)$ appeared at a significantly higher rate than self-regulatory behaviours $(M=2.36, S D=0.69)$, $p<.001, r=.80$ which in turn appeared at a significantly higher rate than coregulation $(M=1.61, S D=0.83), p<.001, r=.68$. 
Hypothesis 3: Different Directions of Activity (Towards Fundamental, Surface Or Group Organisation Aspects) Appear at Differing Degrees during Children's Metacognitive Regulation Behaviours within Musical Play

Because this element was only coded for metacognitive regulation behaviours, it was decided to calculate the percentages of each direction of activity. Out of all the metacognitive regulation behaviours a child displayed during musical play, percentages were calculated relating to what proportion was fundamental to the task, directed to surface aspects of the task or related to organisation of group-work.

The main effect of direction of activity was significant. The differences between the percentages of metacognitive regulation behaviours according to the activity's direction (towards fundamental aspects, surface aspects or organisation of group-work) were significant, $F(1.25,42.64)=2860.82, p<$ .001 . Mauchly's test indicated that the assumption of sphericity had been violated $\chi^{2}(2)=29.82, p<.001$, and the multivariate tests reported $(\varepsilon=.63)$ agree with the above-mentioned result, $V=.99, F(2,33)=4546.94, p<.001$. 


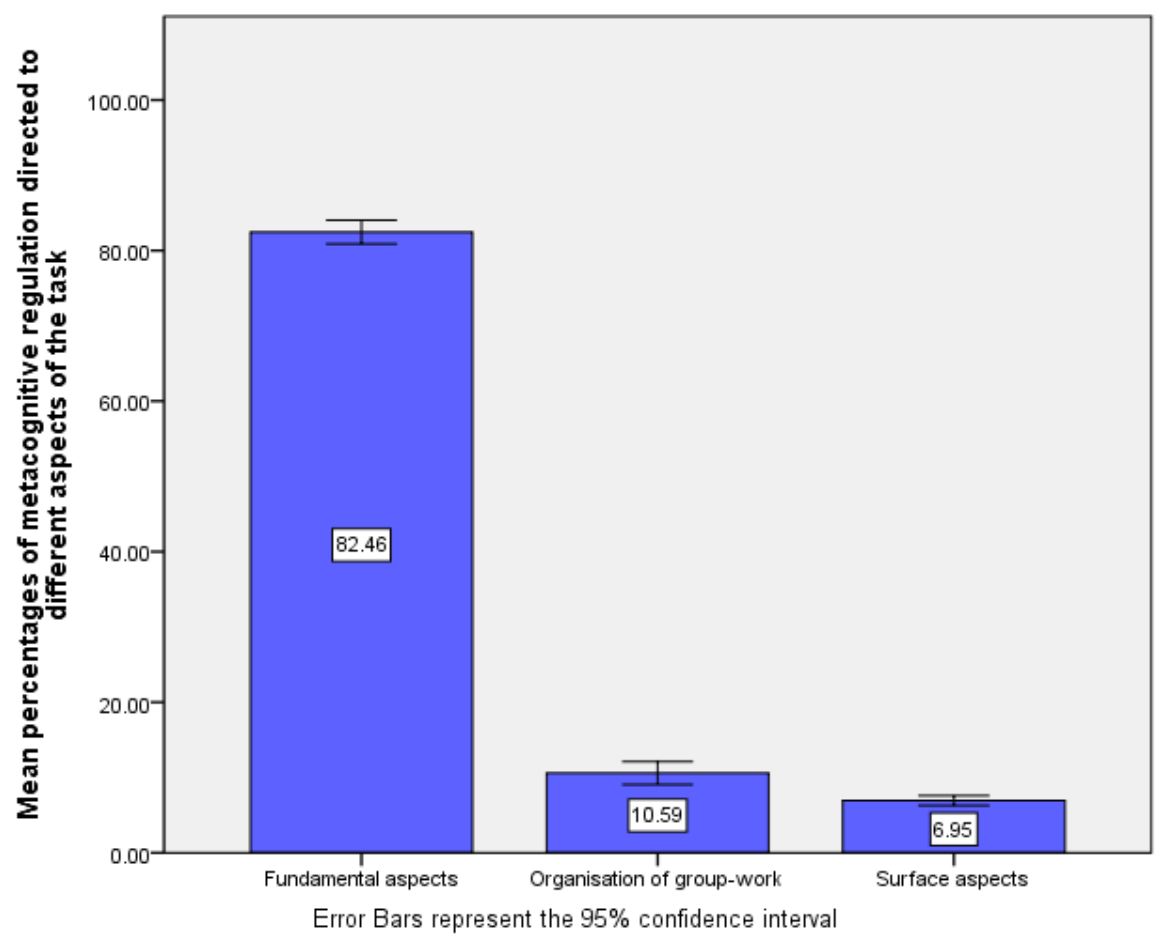

Figure 4. Bar graph of mean percentages of metacognitive regulation behaviours per direction of activity.

According to post-hoc tests, all the percentages of metacognitive regulation behaviours with different directions of activity were significantly different between each other. As illustrated in Figure 4, the percentage of metacognitive regulation behaviours directed towards fundamental aspects of the tasks $(M=82.46 \%, S D=4.64 \%)$ was significantly higher than the percentage of behaviours directed to organisation of group-work $(M=10.59 \%$, $S D=4.52 \%), p<.001, r=.99$, which in turn was significantly higher than the percentage of behaviours directed towards surface aspects $(M=6.95 \%$, $S D=1.93 \%), p=.001, r=.58$. 


\section{Discussion}

\section{Limitations and Challenges}

This study's pioneering nature deemed necessary an in-depth exploration, which consequently dictated the focus on a small sample. It must be acknowledged that because of the particularity of this study's sample and context, which was carefully selected to encourage externally prompted musical play and allow for the emergence of regulatory behaviours, there are problems of inbuilt bias. Thus the claims that can be made are of limited breadth. Furthermore, interaction effects with extraneous factors might have been missed, while it is impossible to determine whether the findings are specific to the group, the particular musical play tasks and contexts studied or if they can be generalised. Therefore the findings presented here can only be understood within the framework of the musical play tasks employed.

Additionally, the fact that the study was based on direct observations of the children's musical play raises the issue of the interpretation of observations, which needs to be made with great caution. This need, as argued by Whitebread and Pino-Pasternak (2013) and Volet and Summers (2013), becomes pertinent in the study of regulation and inter-personal regulation, where the researcher has to deal with intra-mental and socially-based phenomena. Given the socially-based kind of framework used in this study, a higher degree of inference and a shared cultural understanding was involved in the coding of the children's behaviour (Whitebread et al., 2009b). In order to address this issue, as argued by these commentators, the video-data was collected over a sufficiently long episode of activity and non-verbal evidence was used to provide contextual cues to support interpretation of behaviours. This had the implication that all the videos had to be watched in a diligent and exhaustive manner in order to identify explicit non-verbal cues, and this procedure was strengthened through the involvement of a second observer.

Taking the afore-mentioned limitations into consideration, what has been established in this study is presented in the following section.

\section{Significance of the Results}

The fundamental finding that the musical play activities afforded for regulatory behaviours to occur was particularly significant, since it 


\section{Zachariou \& Whitebread-New Context Affording for Regulation}

corroborates previous indications that musical play functions towards regulation in the same way as other types of play (Zachariou \& Whitebread, 2015). It is noteworthy that the rate at which regulatory behaviours emerged during musical play is comparable to -and indeed higher than- the results from the CIndLe study (Whitebread et al., 2009), in which 3-5 year-olds showed a mean rate of 6.92 regulatory behaviours per minute. Even though the different nature of the CIndLe study (different age groups and different contexts) is explicitly acknowledged, this comparison was considered beneficial in order to situate the present study in a wider context. It could be speculated that it was the nature of musical play that encouraged more regulatory behaviours. This claim can only be very tentatively made and further research could usefully focus on providing the tools and data for a comparison between musical play and other types of play.

The predominance of metacognitive regulation behaviours compared to emotional/motivational regulation behaviours, which in turn were more frequent than metacognitive knowledge behaviours is also a very significant result. In particular, it was striking that in musical play emotional/motivational regulation behaviours were more frequent than metacognitive knowledge behaviours, in comparison to what happens in playful situations in general, where metacognitive regulation seems to be the most frequently coded type of regulation, followed by metacognitive knowledge and with emotional/motivational regulation appearing the least often (Whitebread et al. 2009a). This serves as an initial hint that musical play has a particular relationship with emotional/motivational regulation; a finding which also calls for further investigation. Additionally, the prevalence of monitoring, planning and control behaviours in musical play confirms previous findings (Zachariou \& Whitebread, 2015) that musical play acts in line with playful situations in general (Whitebread et al, 2009b). Most importantly, the predominance of emotional/motivational monitoring (being the second most frequently coded behaviour following monitoring) was a surprising result, yet in agreement with the previously discussed findings which comprise initial indications that emotional/ motivational aspects of regulation might have a significant role to play in the link between regulation and musical play.

One of the most ground-breaking results of this study lies in the finding that the musical play activities predominantly afforded for high rates of 
socially-shared regulation compared to self-regulation and co-regulation. The significance of these results arises when compared with previous studies reporting that self-regulation was the most frequently coded type of social intentionality (Whitebread et al., 2007) and noting a relative absence of highlevel socially-shared regulatory behaviours in school collaborative environments (Hurme \& Jarvela, 2005). It is, thus, intriguing that during musical play socially-shared regulation behaviours were the most frequently observed, in contrast to what has been reported in research on other group learning activities.

The finding that opportunities to share regulation between group members (i.e. engaging in socially-shared regulation) were observed most frequently could be aligned with the findings by Rabinowitch, Cross and Burnard (2013) that music promotes social-emotional capacities. This could be attributed to the inherently social nature of musical play (e.g. Marsh \& Young, 2007; Pound, 2010). This social nature promotes a sense of joint action (Rabinowitch et al, 2013), strengthens the sense of acting together in unity (Kirschner \& Tomasello, 2010) and affords interdependency and intersubjectivity (Bannan \& Woodward, 2009; Rabinowitch et al., 2012, 2013), while at the same time prompting dynamic, coordinated and interdependent work. All of these are also characteristics of tasks that provide greater affordance for shared regulation (e.g. Perry \& Winne, 2013; Winne et al., 2013). Given these findings, it can therefore be tentatively argued that the link this study attempted to make between the concepts of regulation and musical play which both appear to have their origins in intersubjectivity (Brinck \& Liljenfors, 2013; Trevarthen \& Aitken, 2001), was indeed a successful one. However, given the limitations of this single study, it cannot be plausibly established that musical play in general mainly encourages socially-shared regulation, until further research corroborates these results.

Finally, the finding that during musical play significantly higher percentages of metacognitive regulation behaviours were directed towards fundamental aspects of the tasks instead of surface or organisational aspects acquires great significance when examined in light of previous research linking this to higher quality regulation. During collaborative mathematics (Rogat \& Linnenbrink-Garcia, 2011) and science tasks (Grau \& Whitebread, 2012) low quality regulation and directing activity towards surface aspects 


\section{Zachariou \& Whitebread-New Context Affording for Regulation}

(respectively) were the norm. The comparison with these results strengthens the case in favour of the musical play activities being engaging, motivating, successful in stimulating genuinely goal-directed regulation and affording regulatory behaviours. It is thus made evident that the present study's interest in investigating the quality differences in regulation was of added value, since the findings made it possible to posit that musical play may afford for higher quality of regulation.

\section{Implications}

The establishment that these musical play activities afforded for regulatory behaviours could have both theoretical and practical significance. From a theoretical point of view, it provides further support to the theories advocating for a link between play and regulation, while expanding the literature on the range of activities affording for regulation, and revealing a new route through which musicality is linked to cognitive benefits.

This, in turn, could have practical implications for education since it could affect the strategies adopted in schools to encourage regulatory development. Since metacognitive abilities are considered teachable (Dignath et al., 2008; Hattie et al, 1996) and teaching strategies fostering metacognition and regulation have been shown to be the most effective in the improvement of learning (Higgins, 2013), musical play could be incorporated in the curriculum as an integral part of these strategies.

Furthermore, due to its inherent characteristic of interdependency, musical play is also a context positively associated with genuine group-work, which requires a set of skills currently receiving increasing attention in the school context (Organisation for Economic Co-operation and Development, 2013). The added value of the present study lies in the fact that during musical play socially-shared regulation appears to be the most frequently coded type of social intentionality (Hypothesis 2). Thus, musical play could provide a platform from where to enhance these highly valued collaborative problemsolving, socially-shared regulation abilities.

As has been previously suggested in the literature, it is therefore important that teachers are informed of this evidence (Whitebread, 2013) and enabled to embed these practices in their classrooms. In doing so, the evidence from this study, in light of other studies examining teaching practices that afford for 
regulation, suggests that they could have a greatly enhanced impact on children's academic and personal development.

\section{Conclusion}

The current paper introduces musical play as a new context affording for regulation. In line with other contexts, musical play mainly affords for monitoring behaviours, but also fosters emotional/motivational monitoring behaviours. Importantly, in marked contrast to other contexts, musical play potentially due to its inherent intersubjectivity- appears to be a fertile context for socially-shared regulation, and for regulatory activity directed towards fundamental aspects of the tasks. The results highlight the importance of a detailed, multi-dimensional approach in the study of different aspects of regulatory behaviours, which although labour-intensive, provided very useful insights into the affordances of musical play. These results and approach can be considered crucial to informing self-regulation research and practice and establishing musical play's importance in this regard.

\section{Acknowledgements}

The authors wish to thank the teachers and all the children who participated in this research. This project was partially funded by the A.G.Leventis Foundation. The funding source had no involvement in the study design; in the collection, analysis or interpretation of data; in the writing of the report; or in the decision to submit the article for publication.

\section{Notes}

\footnotetext{
${ }^{1}$ The term 'self-regulation' is employed in this Introduction to reflect the literature's traditional focus on self-regulation and to allow for an accurate presentation of the concept's definition as coined by Vygotsky.

${ }^{2}$ From here onwards, the terms 'regulation' or 'regulatory behaviour' are used as umbrella terms when the authors wish to refer to all types of social intentionality and include self-, coand socially-shared regulation. The terms self-, co-, and socially-shared regulation are used when the authors wish to differentiate according to social intentionality.
} 


\section{Zachariou \& Whitebread-New Context Affording for Regulation}

${ }^{3}$ The CHILD achieves high levels of internal consistency amongst its 22 statements (Cronbach alpha $=.97$ ), and provides high inter-rater reliability (level of agreement $=85.9 \%$ ) (Whitebread et al., 2009b)

\section{References}

Bannan, N., \& Woodward, S. (2009). Spontaneity in the musicality and music learning in children. In S. Malloch \& C. Trevarthen (Eds.), Communicative Musicality. Exploring the basis of human companionship (pp. 465-494). Oxford: Oxford University Press. Barrett, M. S. (2009). Sounding lives in and through music a narrative inquiry of the 'everyday'musical engagement of a young child. Journal of Early Childhood Research, 7(2), 115-134. doi:10.1177/1476718X09102645

Baumeister, R., \& Vohs, K. (Eds.). (2004). Handbook of self-regulation. New York: Guilford Press.

Berk, L. E., Mann, T., \& Ogan, A. (2006). Make-believe play: Wellspring for Development of Self-Regulation. In D. Singer, R. Golinkoff, \& K. Hirsh-Pasek (Eds.), Play=Learning. How play motivates and enhances children's cognitive and social-emotional growth (pp. 74100). USA: Oxford University Press.

Boekaerts, M., \& Niemivirta, M. (2000). Self-regulated learning: Finding a balance between learning goals and ego-protective goals. In M. Boekaerts, P. Pintrich, \& M. Zeidner (Eds.), Handbook of selfregulation (pp. 417-450). San Diego, CA: Academic.

Brinck, I., \& Liljenfors, R. (2013). The developmental origin of metacognition. Infant and Child Development, 22(1), 85-101. doi:10.1002/icd.1749

Bronson, M. (2000). Self-regulation in early childhood: Nature and nurture. New York: Guilford Press.

Bruner, J. S. (1972). Nature and uses of immaturity. American Psychologist, 27(8), 687-708.

Coltman, P., Warwick, J., Wilmott, J., Pino-Pasternak, D., \& Whitebread, D. (2013). Teachers co-constructing pedagogical practices to support children's exploratory talk and self-regulation: the Children Articulating Thinking (ChAT) project. Self-Regulation and Dialogue 
in Primary Classrooms, Monograph Series II: Psychological Aspects of Education-Current Trends (10), 127-146.

Custodero, L. (2009). Intimacy and reciprocity in improvisatory musical performance: Pedagogical lessons from adult artists and young children. In S. Malloch \& C. Trevarthen (Eds.), Communicative Musicality. Exploring the basis of human companionship (pp. 513529). Oxford: Oxford University Press.

Dignath, C., Buettner, G., \& Langfeldt, H.P. (2008). How can primary school students learn self-regulated learning strategies most effectively? A meta-analysis on self-regulation training programmes. Educational Research Review, 3(2), 101-129. doi:10.1016/j.edurev.2008.02.003

Fantuzzo, J., Sekino, Y., \& Cohen, H. L. (2004). An examination of the contributions of interactive peer play to salient classroom competencies for urban head start children. Psychology in the Schools, 41(3), 323-336. doi:10.1002/pits.10162

Galyer, K. T., \& Evans, I. M. (2001). Pretend play and the development of emotion regulation in preschool children. Early Child Development and Care, 166(1), 93-108. doi:10.1080/0300443011660108

Golinkoff, R. ., Hirsh-Pasek, K., \& Singer, D. (2008). Why Play = Learning: A challenge for parents and educators. In D. Singer, R. Golinkoff, \& K. Hirsh-Pasek (Eds.), Play = Learning. How play motivates and enhances children's cognitive and social-emotional growth (pp. 315). New York: Oxford University Press.

Grau, V., \& Whitebread, D. (2012). Self and social regulation of learning during collaborative activities in the classroom: The interplay of individual and group cognition. Learning and Instruction, 22(6), 401412. doi: 10.1016/j.learninstruc.2012.03.003

Hacker, D., Dunlosky, J., \& Graesser, A. (Eds.). (1998). Metacognition in educational theory and practice. London: Lawrence Erlbaum.

Hadwin, A. F., Järvelä, S., \& Miller, M. (2011). Self-regulated, co-regulated, and socially shared regulation of learning. In B.J. Zimmerman, \& D.H.Schunk (Eds.), Handbook of Self-Regulation of Learning and Performance (pp. 65-86). New York: Routledge. 
Hadwin, A. F., Oshige, M., Gress, C. L., \& Winne, P. H. (2010). Innovative ways for using gStudy to orchestrate and research social aspects of self-regulated learning. Computers in Human Behaviour, 26(5), 794805. doi:10.1016/j.chb.2007.06.007

Hallam, S. (2007). Musicality. In G. McPherson (Ed.), The child as musician: A handbook of musical development. (pp. 93-110). USA: Oxford University Press.

Harwood, E. (1998). Music learning in context: A playground tale. Research Studies in Music Education, 11(1), 52-60.

doi:10.1177/1321103X9801100106

Hattie, J., Biggs, J., \& Purdie, N. (1996). Effects of learning skills interventions on student learning: A meta-analysis. Review of Educational Research, 66(2), 99-136. doi:10.3102/00346543066002099

Higgins, S. (2013). Self-regulation and learning : evidence from metaanalysis and from classrooms. The British Journal of Educational Psychology, Monograph Series II: Psychological Aspects of Education-Current Trends, 111-126.

Hirsh-Pasek, K., Golinkoff, R. ., Berk, L. E., \& Singer, D. (2008). A mandate for playful learning in preschool: presenting the evidence. New York: Oxford University Press.

Hurme, T.R., \& Järvelä, S. (2005). Students' activity in computer-supported collaborative problem solving in mathematics. International Journal of Computers for Mathematical Learning, 10(1), 49-73. doi:10.1007/s10758-005-4579-3

Iiskala, T., Vauras, M., \& Lehtinen, E. (2004). Socially shared metacognition in peer-learning? Hellenic Journal of Psychology, 1, $147-178$.

Janssen, J., Erkens, G., Kirschner, P. A., \& Kanselaar, G. (2012). Taskrelated and social regulation during online collaborative learning. Metacognition and Learning, 7(1), 25-43.

Järvelä, S., \& Hadwin, A. F. (2013). New frontiers: Regulating learning in CSCL. Educational Psychologist, 48(1), 25-39. doi:10.1080/00461520.2012.748006 
Järvelä, S., Järvenoja, H., Malmberg, J., \& Hadwin, A. F. (2013). Exploring Socially Shared Regulation in the Context of Collaboration. Journal of Cognitive Education and Psychology, 12(3), 267-286.

Kirschner, S., \& Tomasello, M. (2010). Joint music making promotes prosocial behaviour in 4-year-old children. Evolution and Human Behaviour, 31(5), 354-364. doi:10.1016/j.evolhumbehav.2010.04.004 Lew, J. C.T., \& Campbell, P. S. (2005). Children's Natural and Necessary Musical Play: Global Contexts, Local Applications. Music Educators Journal, 91(5), 57-63.

Marsh, K. (2008). The musical playground: global tradition and change in children's songs and games. Oxford: Oxford University Press.

Marsh, K., \& Young, S. (2007). Musical Play. In G. McPherson (Ed.), The child as musician: A handbook of musical development. (pp.289-310). USA: Oxford University Press.

McCaslin, M., \& Good, T. (1996). The Informal Curriculum. In D. Berliner \& R. Calfee (Eds.), Handbook of educational psychology (pp. 622670). USA: Macmillan.

McClelland, M. M., \& Tominey, S. L. (2011). Introduction to the special issue on self-regulation in early childhood. Early Education \& Development, 22(3), 355-359. doi:10.1080/10409289.2011.574265

Organisation for Economic Co-operation and Development. (2013, March). PISA 2015: Draft collaborative problem solving framework.

Retrieved from

http://www.oecd.org/pisa/pisaproducts/DraftPISA2015CollaborativeP roblemSolvingFramework.pdf

Papousek, H. (1996). Musicality in infancy research: biological and cultural origins of early musicality. In I. Deliege \& J. Sloboda (Eds.), Musical beginnings: Origins and development of musical competence (pp. 3755). Oxford: Oxford University Press.

Perry, N. E., \& Winne, P. H. (2013). Tracing students' regulation of learning in complex collaborative tasks. In S. Volet \& M. Vauras (Eds.), New perspectives on learning and instruction. Interpersonal regulation of learning and motivation (pp. 45-66). USA: Routledge.

Pond, D. (1980). The Young Child's Playful World of Sound. Music Educators Journal, 66(7), 39-41. 
Pound, L. (2010). Playing music. In J. Moyles (Ed.), The excellence of play (pp. 139-153). Maidenhead: Open University Press.

Rabinowitch, T.C., Cross, I., \& Burnard, P. (2012). Music group interaction, intersubjectivity and merged subjectivity. In D. Reynolds \& M.

Reason (Eds.), Kinesthetic empathy in creative and cultural prectives (pp. 109-120). Bristol, UK: Intellect.

Rabinowitch, T.C., Cross, I., \& Burnard, P. (2013). Long-term musical group interaction has a positive influence on empathy in children.

Psychology of Music, 41(4), 484-498.

doi:10.1177/0305735612440609

Rodríguez, C., \& Palacios, P. (2007). Do private gestures have a selfregulatory function? A case study. Infant Behaviour and

Development, 30(2), 180-194. doi:10.1016/j.infbeh.2007.02.010

Rogat, T. K., \& Linnenbrink-Garcia, L. (2011). Socially shared regulation in collaborative groups: An analysis of the interplay between quality of social regulation and group processes. Cognition and Instruction, 29(4), 375-415. doi:10.1080/07370008.2011.607930

Tarnowski, S. M. (1999). Musical play and young children: A music teacher can enhance a child's learning and development by encouraging musical play activities. Music Educators Journal, 86(1), 26-29.

Teddlie, C., \& Yu, F. (2007). Mixed methods sampling a typology with examples. Journal of Mixed Methods Research, 1(1), 77-100. doi:10.1177/2345678906292430

Trevarthen, C. (2000). Musicality and the intrinsic motive pulse: evidence from human psychobiology and infant communication. Musicae Scientiae, 3(1), 155-215. doi:10.1177/10298649000030S109 Trevarthen, C. (2012). Communicative musicality: The human impulse to create and share music. In D. Hargreaves, D. Miell, \& R. MacDonald (Eds.), Musical imaginations. Multidisciplinary perspectives on creativity, performance and perception (pp. 259-284). New York: Oxford University Press.

Trevarthen, C., \& Aitken, K. J. (2001). Infant intersubjectivity: Research, theory, and clinical applications. Journal of Child Psychology and Psychiatry, 42(1), 3-48. doi:10.1017/S0021963001006552 
Vallotton, C. D. (2008). Signs of emotion: What can preverbal children "say" about internal states? Infant Mental Health Journal, 29(3), 234258. doi:10.1002/imhj.20175

Veenman, M. V. (2011). Learning to self-monitor and self-regulate. In R. Mayer \& P. Alexander (Eds.), Handbook of research on learning and instruction (pp. 197-218). New York: Routledge.

Veenman, M. V., Van Hout-Wolters, B. H., \& Afflerbach, P. (2006).

Metacognition and learning: Conceptual and methodological considerations. Metacognition and Learning, 1(1), 3-14. doi:10.1007/s11409-006-6893-0

Volet, S., \& Summers, M. (2013). Interpersonal regulation in collaborative learning activities. Reflections on emerging research methodologies. In S. Volet \& M. Vauras (Eds.), New perspectives on learning and instruction. Interpersonal regulation of learning and motivation (pp. 204-217). USA: Routledge.

Volet, S., Vauras, M., \& Salonen, P. (2009). Self-and social regulation in learning contexts: An integrative perspective. Educational Psychologist, 44(4), 215-226. doi:10.1080/00461520903213584

Vygotsky, L. S. (1978). Mind and society: The development of higher mental processes. (M. Cole, V. John-Steiner, S. Scribner, \& E. Souberman, Eds.). Cambridge, MA: Harvard University Press.

Whitebread, D. (2013). Self-regulation in young children: its characteristics and the role of communication and language in its early development. The British Journal of Educational Psychology, Monograph Series II: Psychological Aspects of Education- Current Trends(10), 25-44.

Whitebread, D., Almeqdad, Q., Bryce, D., Demetriou, D., Grau, V., \& Sangster, C. (2010). Metacognition in Young Children: Current Methodological and Theoretical Developments. In A. Efklides \& P. Misailidi (Eds.), Trends and Prospects in Metacognition Research (pp. 233-258). New York: Springer.

Whitebread, D., Bingham, S., Grau, V., Pino Pasternak, D., \& Sangster, C. (2007). Development of metacognition and self-regulated learning in young children: Role of collaborative and peer-assisted learning. Journal of Cognitive Education and Psychology, 6(3), 433-455. doi:10.1891/194589507787382043 
Whitebread, D., Coltman, P., Jameson, H., \& Lander, R. (2009a). Play, cognition and self-regulation: What exactly are children learning when they learn through play? Educational and Child Psychology, 26(2), 40-52.

Whitebread, D., Coltman, P., Pasternak, D. P., Sangster, C., Grau, V., Bingham, S., Almeqdad, Q., Demetriou, D. (2009b). The development of two observational tools for assessing metacognition and selfregulated learning in young children. Metacognition and Learning, 4(1), 63-85. doi:10.1007/s11409-008-9033-1

Whitebread, D., \& Pino-Pasternak, D. (2013). Video analysis of selfregulated learning in social and naturalistic contexts. The case of preschool and primary school children. In S. Volet \& M. Vauras (Eds.), New perspectives on learning and instruction. Interpersonal Regulation of Learning and Motivation (pp. 14-44). USA: Routledge. Winne, P. H., Hadwin, A. F., \& Perry, N. E. (2013). Metacognition and Computer-Supported Collaborative Learning. In C. Hmelo-Silver, C. Chinn, C. K. Chan, \& A. O'Donnell (Eds.), The International Handbook of Collaborative Learning (pp. 462-479). New York: Taylor \& Francis.

Winsler, A., Ducenne, L., \& Koury, A. (2011). Singing one's way to selfregulation: The role of early music and movement curricula and private speech. Early Education and Development, 22(2), 274-304. doi:10.1080/10409280903585739

Young, S. (2003). Music with the under-fours. London: RoutledgeFalmer. Young, S. (2004). The interpersonal dimension: a potential source of musical creativity for young children? Musicae Scientiae, 7(1 suppl), 175-191. doi:10.1177/10298649040070S109

Young, S. (2005). Adults and young children communicating musically. In D. Hargreaves, D. Miell, \& D. MacDonald (Eds.), Musical Communication (pp. 281-299). Oxford: Oxford University Press. Zachariou, A., \& Whitebread, D. (2015). Musical play and self-regulation: Does musical play allow for the emergence of self-regulatory behaviours? International Journal of Play, 4(2), 116-135. doi:10.1080/21594937.2015.1060572 
Zimmerman, B. J. (1989). A social cognitive view of self-regulated academic learning. Journal of Educational Psychology, 81(3).

Antonia Zachariou is Lecturer in Early Childhood Studies, School of Education, University of Roehampton. ORCID identifier: 0000-00024598-8409

David Whitebread is Acting Director (External Relations), PEDAL Research Centre, University of Cambridge.

Contact Address: Antonia Zachariou. School of Education, University of Roehampton, Roehampton Lane, SW15 5PJ, London, UK. Email: Antonia.zachariou@roehampton.ac.uk 


\section{Appendices}

Appendix A: Examples of musical play activities

\begin{tabular}{ll}
\hline Type of musical play & $\begin{array}{l}\text { Activity } \\
\text { The children were encouraged to: }\end{array}$ \\
\hline Movement play & $\begin{array}{l}\text { Dance to a musical piece, firstly on their own and } \\
\text { then in groups of three. } \\
\text { Play hand-clapping games they already knew, in } \\
\text { pairs. } \\
\text { Learn a rhyme involving hand-clapping, to play with } \\
\text { this rhyme and find other ways of hand-clapping in } \\
\text { pairs. }\end{array}$ \\
Learn a game played in a circle while holding hands. \\
Then play other games they knew that are played in a \\
circle (in groups of seven). \\
Create music inspired by an image (that had been \\
introduced to them) on their own and then in groups \\
of three. \\
Think of a phrase (having an image as the incentive) \\
and 'say it till a song comes', firstly individually and \\
then playing in their groups to create their own songs.
\end{tabular}


Appendix B: Examples of different types of regulatory behaviour observed during musical play

\begin{tabular}{|c|c|}
\hline $\begin{array}{l}\text { General areas and } \\
\text { specific types of regulation }\end{array}$ & Examples \\
\hline \multicolumn{2}{|l|}{ Metacognitive knowledge } \\
\hline \multirow[t]{2}{*}{ Knowledge of persons } & I don't want to sing; I am not good at it \\
\hline & $\begin{array}{l}\text { Do you know why (I am doing this so well)? I have been } \\
\text { practising! }\end{array}$ \\
\hline \multirow[t]{2}{*}{ Knowledge of tasks } & $\begin{array}{l}\text { Explains what the task lacks in comparison to other ideas. } \\
\text { [to peer] Ah, it is too difficult! }\end{array}$ \\
\hline & $\begin{array}{l}\text { Identifies similarities to hand-clapping games they already } \\
\text { know [Hand-clapping] }\end{array}$ \\
\hline Knowledge of strategies & $\begin{array}{l}\text { Explains to the rest of the group the game. You will be } \\
\text { closing the circle when I enter the circle and you will be } \\
\text { singing this [Circle games] }\end{array}$ \\
\hline \multicolumn{2}{|l|}{ Metacognitive regulation } \\
\hline \multirow[t]{3}{*}{ Planning } & $\begin{array}{l}\text { Child tries to get the team ready and at the correct position } \\
\text { before the start of play. }\end{array}$ \\
\hline & Directs who plays what and when. \\
\hline & $\begin{array}{l}\text { Gets his peer's hands ready in the correct position before } \\
\text { they start playing [Hand-clapping]. }\end{array}$ \\
\hline Monitoring & $\begin{array}{l}\text { Checking around their peers to make sure they are doing it } \\
\text { correctly. Commenting on the song. Monitoring their play } \\
\text { while on task }\end{array}$ \\
\hline \multirow[t]{3}{*}{ Control } & $\begin{array}{l}\text { Guides another child by demonstration of how the } \\
\text { instrument should be used }\end{array}$ \\
\hline & $\begin{array}{l}\text { Nods to a peer to point out it is her turn to move [Movement } \\
\text { play]. }\end{array}$ \\
\hline & $\begin{array}{l}\text { 'One, two, three'-implementing a known strategy to a new } \\
\text { situation }\end{array}$ \\
\hline \multirow[t]{2}{*}{ Evaluation } & We've made a song! It's perfect! [Singing play] \\
\hline & $\begin{array}{l}\text { This dance (we are creating) fits really well with the } \\
\text { song. [Movement play] }\end{array}$ \\
\hline \multicolumn{2}{|c|}{ Emotional and motivational regulation } \\
\hline $\begin{array}{l}\text { Emotional/motivational } \\
\text { monitoring }\end{array}$ & $\begin{array}{l}\text { I don't want to sing. [Singing play] } \\
\text { Smiling, laughing, pulling a long face. Looking excited. }\end{array}$ \\
\hline \multirow[t]{2}{*}{$\begin{array}{l}\text { Emotional/motivational } \\
\text { control }\end{array}$} & $\begin{array}{l}\text { Nods her head encouragingly to make a peer dance [Circle } \\
\text { games]. }\end{array}$ \\
\hline & $\begin{array}{l}\text { His peer is not paying attention to him but he still persists } \\
\text { trying to get his hands in the correct position for the start of } \\
\text { the game [hand-clapping games]. }\end{array}$ \\
\hline
\end{tabular}

Examples coded according to the C.Ind.Le coding framewor 
Appendix C: Examples of regulatory behaviours of different social intentionality

\begin{tabular}{ll}
\hline $\begin{array}{l}\text { Social } \\
\text { Intentionality }\end{array}$ & Example \\
\hline Self-regulation & $\begin{array}{l}\text { Child realises that he made a mistake and played his } \\
\text { instrument at the wrong moment. Immediately self-corrects } \\
\text { and stops. }\end{array}$ \\
& $\begin{array}{l}\text { Following moving on the musical piece in the way he had } \\
\text { suggested, stops and announces 'I am bored of this one } \\
\text { (this pattern of moves)' }\end{array}$ \\
& $\begin{array}{l}\text { Closely monitoring another child's effort and nodding her } \\
\text { head in approval. }\end{array}$ \\
Co-regulation & $\begin{array}{l}\text { One of the group members misbehaves. Another child } \\
\text { raises the tone of her voice and touches him on the knee, } \\
\text { saying in a slightly annoyed tone: 'Hey, come on' } \\
\text { (Behave!). }\end{array}$ \\
Socially-shared & $\begin{array}{l}\text { All children in the group are discussing their ideas for the } \\
\text { lyrics of their song together, with everyone suggesting an } \\
\text { idegulation }\end{array}$
\end{tabular}


Appendix D: Examples of regulatory behaviours having different directions of activity

Direction of Example
activity

Fundamental Discussing about the moves they will do on the music.

aspects

[Movement play].

Child gets peer's hands ready before the start of the game [Hand-clapping].

Checking if the peers in the circle are doing the moves correctly [Circle games].

Discussing about the lyrics of their song or its rhythm [Singing play].

Surface aspects Getting the 'stage' ready for their dance [Movement play].

Discussing about particular aspects of the task, like which hand one uses to show they have won [Hand-clapping games].

Talking about the finger puppets they are holding [Singing play].

Organisation of Giving signals to each other on when to start moving group-work [Movement play].

Saying 'first you will play, then you' [Instrumental play]. 